\title{
Hubungan Status Gizi Bayi dengan Pemberian ASI Ekslusif, Tingkat Pendidikan Ibu dan Status Ekonomi Keluarga di Wilayah Kerja Puskesmas Padang Pasir
}

\author{
Aisyah Nilakesuma ${ }^{1}$, Yusri Dianne Jurnalis ${ }^{2}$, Selfi Renita Rusjdi ${ }^{3}$
}

\begin{abstract}
Abstrak
Status gizi merupakan salah satu tolak ukur untuk menilai perkembangan kesehatan bayi. Banyak faktor yang dapat mempengaruhi status gizi seorang bayi, diantaranya pemberian ASI ekslusif, tingkat pendidikan ibu dan status ekonomi keluarga. Tujuan penelitian ini adalah untuk melihat hubungan antara status gizi bayi dengan pemberian ASI ekslusif, tingkat pendidikan ibu dan status ekonomi keluarga. Telah dilakukan penelitian Cross Sectional Analytic di wilayah kerja Puskesmas Padang Pasir. Data diambil melalui pengukuran langsung berat badan/tinggi badan dan wawancara dengan kuesioner terhadap 107 responden, kemudian dianalisis dengan uji chi square. Hasil penelitian terhadap 107 bayi didapatkan sebanyak 82,2\% bayi berstatus gizi normal dan hanya 18,7\% bayi yang diberi ASI ekslusif, sedangkan terhadap ibu diperoleh data: 76,6\% berpendidikan tinggi dan 80,4\% merupakan keluarga tidak miskin. Bayi yang mendapat ASI ekslusif $80 \%$ berstatus gizi normal. Menurut tingkat pendidikan ibu, didapatkan $82,9 \%$ bayi berstatus gizi normal memiliki ibu berpendidikan tinggi. Sedangkan menurut status ekonomi keluarga, bayi yang berada pada keluarga tidak miskin sebanyak $83,7 \%$ berstatus gizi normal.
\end{abstract}

Kata kunci: status gizi, ASI ekslusif, tingkat pendidikan ibu, status ekonomi keluarga

\begin{abstract}
Nutritional status is one yardstick for assessing health an infant development. There are many factors that can influence the nutritional status of infant, which are exclusive breastfeeding, mother educational status, and economic status of family. This research aimed to determine the relationship between infant nutritional status exclusive breastfeeding, mother educational status, and economic status of family. The research has been conducted about the relationship between infant nutritional status with exclusive breastfeeding, mother educational status, and economic status of family in working area of Padang Pasir Health Care. Data were taken by measurement directly for weight/height and interviewed with questionnaire to 107 respondents. Data were analyzed by using chi square. The result showed that $82,2 \%$ infant have normal status of nutrition and only $18,7 \%$ of infants who were given exclusive breastfeeding. While the result of research on the mother of respondents, then obtained a total of $76,6 \%$ highly educated and $80,4 \%$ constituting the family not be poor. Nutritional status of an infant who gets exclusive breastfeeding, $80 \%$ has normal nutrition status. According to the level of education mother, infant who possess the mother with the level of higher education, $82,9 \%$ the status is normal nutrition. And according to the economy of a family, an infant from familiy that were not poor $83,7 \%$ the status is normal nutrition.
\end{abstract}

Keywords: nutritional status, exclusive breastfeeding, mother educational status, economic status of family

Affiliasi penulis : 1. Pendidikan Dokter FK UNAND (Fakultas Kedokteran Universitas Andalas Padang), 2. Bagian IImu Kesehatan Anak FK UNAND/RSUP Dr. M. Djamil Padang, 3. Bagian Parasitologi FK UNAND

Korespondensi :Aisyah Nilakesuma, E-mail : aisyah2991@gmail.com, Telp: 085263865558

\section{PENDAHULUAN}

Pembangunan nasional pada dasarnya adalah membangun manusia Indonesia seutuhnya dan pembangunan masyarakat Indonesia seluruhnya. Demi terwujudnya pembangunan nasional, maka perlu 
dilakukan secara menyeluruh di segala aspek kehidupan bangsa. Sumber Daya Manusia (SDM) yang berkualitas merupakan syarat mutlak terwujudnya pembangunan di segala bidang. Status gizi menjadi salah satu faktor yang sangat berperan penting pada kualitas SDM terutama yang terkait dengan kecerdasan, produktivitas dan kreativitas. Jika status gizi masyarakat baik, dapat menunjang intelektualitas, produktifitas serta prestasi kerja dari masyarakat tersebut. ${ }^{1,2}$

Masalah gizi pada dasarnya merupakan masalah kesehatan yang penanggulangannya tidak dapat hanya dilakukan dengan pendekatan medis dan pelayanan kesehatan saja. Oleh karena penyebabnya yang multifaktor, pendekatan penanggulangan masalah gizi harus melibatkan berbagai sektor yang terkait didalamnya. $^{3}$

Anak adalah generasi penerus bangsa yang akan menentukan kesejahteraan dan kejayaan suatu bangsa dan negara. Dalam implementasinya, anak merupakan sumber daya manusia bagi pembangunan suatu bangsa. ${ }^{4}$ Diperlukan perhatian khusus terhadap pemberian gizi sehingga dapat menunjang pertumbuhan dan perkembangan yang lebih baik. Gizi pada masa anak sangat berpengaruh terhadap tumbuh kembang bahkan sejak masih dalam kandungan sekalipun, gizi memegang peranan penting. Apabila ibu hamil mendapat makanan yang adekuat, maka bayi yang dikandungnya akan lahir dengan berat lahir normal. Sedangkan ibu yang kurang gizi, akan melahirkan bayi dengan berat lahir rendah. ${ }^{5}$

Nutrisi terpenting yang diperoleh pertama kali saat bayi lahir adalah ASI. ASI merupakan makanan paling ideal baik secara fisiologis maupun biologis yang harus diberikan kepada bayi di awal kehidupannya. Hal ini dikarenakan selain mengandung nilai gizi yang cukup tinggi, ASI juga mengandung zat kekebalan tubuh yang akan melindungi dari berbagai jenis penyakit yang dapat menghambat petumbuhan bayi tersebut. ${ }^{6}$ Pemberian ASI dimulai sejak bayi dilahirkan selama 6 bulan, tanpa menambahkan dan atau mengganti dengan makanan atau minuman lain. ${ }^{7}$

Pada saat ini, permasalahan gizi yang sedang terjadi di Indonesia merupakan masalah gizi ganda, yaitu masalah gizi kurang dan masalah gizi lebih. Masalah gizi kurang biasanya disebabkan oleh kemiskinan, kurangnya ketersediaan pangan, sanitasi lingkungan yang tidak baik, kurangnya pengetahuan masyarakat tentang gizi, dan adanya daerah miskin gizi. Sedangkan masalah gizi lebih biasanya disebabkan oleh kemajuan ekonomi pada lapisan masyarakat tertentu yang tidak diimbangi dengan peningkatan pengetahuan gizi. ${ }^{8}$

Masalah gizi kurang menjadi salah satu masalah gizi yang belum terselesaikan di Indonesia. Meskipun begitu, prevalensi gizi kurang telah turun dari 31\% pada tahun 1989 menjadi 17,9\% pada tahun 2010. Sementara itu, prevalensi masalah gizi lebih yang tidak hanya dialami anak-anak namun juga pada dewasa meningkat hampir satu persen tiap tahunnya. Prevalensi gizi lebih pada anak-anak dan dewasa, masing-masing 14,4\% pada tahun 2007 dan 21,7\% pada tahun $2010 .^{9}$

Sumatera Barat merupakan salah satu provinsi yang juga mengalami permasalahan gizi. Pada tahun 2010, di provinsi Sumatera Barat dilaporkan sekitar $4 \%$ balita dengan status gizi sangat kurus, $4,2 \%$ kurus, dan $8,3 \%$ berstatus gizi gemuk. ${ }^{10}$ Sementara untuk daerah Padang berdasarkan data yang diperoleh, dilaporkan sebanyak 920 balita (1,76\%) mengalami kasus gizi buruk, 5.592 balita $(10,68 \%)$ mengalami gizi kurang, dan 683 balita $(1,3 \%)$ mengalami gizi lebih. Masalah gizi yang serupa terdapat juga di wilayah kerja Puskesmas Padang Pasir yang terletak di Kecamatan Padang Barat. Dari 3302 balita yang ditimbang disana, terdapat sekitar 33 balita yang mengalami gizi buruk, 226 balita mengalami gizi kurang, dan 43 balita mengalami gizi lebih. $^{11}$

Berdasarkan pada hal-hal tersebut di atas, maka dilakukan penelitian dalam salah satu bidang kegiatan yaitu status gizi bayi, dimana wilayah kerja Puskesmas Padang Pasir merupakan salah satu daerah yang mengalami masalah gizi dan terjangkau oleh tenaga kesehatan.

\section{METODE}

Penelitian ini merupakan penelitian survei deskriptif dalam bentuk rancangan studi potong lintang (cross sectional). Populasi penelitian adalah seluruh ibu beserta bayinya yang berkunjung ke wilayah kerja 
Puskesmas Padang Pasir, sedangkan subjek penelitian berjumlah 107 yang diambil berdasarkan metode simple random sampling. Kriteria inklusi adalah ibu yang bersedia menjadi responden; responden memiliki bayi usia 6 bulan -2 tahun; bayi lahir cukup bulan dengan berat badan lahir cukup. Kriteria ekslusi adalah responden tidak hadir ke lokasi penelitian; responden lupa tanggal, bulan dan tahun lahir bayinya; responden menderita gangguan jiwa, atau tidak dapat berkomunikasi; bayi memiliki penyakit kongenital dan penyakit kronis yang berpotensi mengganggu tumbuh kembang.

Variabel dependen penelitian adalah status gizi bayi yang dilakukan dengan mengukur berat badan bayi berdasarkan panjang badan (BB/TB) bayi kemudian dikonversikan ke dalam standar baku WHO NCHS dan disajikan dalam Z skor. Hasil ukurnya yaitu gemuk ( >+2 SD ), normal ( $\geq-2$ SD sampai +2 SD ), kurus ( $<-2$ SD sampai $\geq-3$ SD ), kurus sekali ( $<-3$ SD ). Kategori diklasifikasikan lagi menjadi normal dan tidak normal. Kategori tidak normal terdiri dari gemuk, kurus, dan kurus sekali. Variabel independen adalah pemberian ASI ekslusif, tingkat pendidikan ibu dan status ekonomi keluarga. ASI eksklusif atau lebih tepatnya pemberian ASI eksklusif adalah pemberian ASI saja selama 6 bulan tanpa tambahan cairan lainnya, seperti susu formula, madu, air teh, air putih, dan tanpa makanan tambahan padat seperti pisang, pepaya, bubur susu, biskuit, bubur nasi dan tim. Data didapatkan dengan cara wawancara menggunakan kuesioner. Tingkat pendidikan ibu dinilai dengan ijazah pendidikan yang pernah didapat. Data didapatkan dengan cara wawancara menggunakan kuesioner dengan hasil ukurnya yaitu rendah jika pendidikan < SMA, tinggi jika pendidikan $\geq$ SMA. Status ekonomi didefinisikan sebagai pendapatan perkapita perbulan dalam keluarga dibagi jumlah anggota keluarga berdasakan Badan Pusat Statistik tahun 2011. Data diperoleh melalui wawancara menggunakan kuesioner dengan hasil ukur miskin, bila pendapatan $\leq \mathrm{Rp}$. 326.705 dan tidak miskin, bila pendapatan> Rp. 326.705.
Analisis data terdiri dari analisis univariat dan bivariat. Analisis bivariat digunakan untuk mengetahui hubungan antara dua variabel yaitu status gizi bayi dengan pemberian asi ekslusif, tingkat pendidikan ibu, dan status ekonomi keluarga menggunakan uji chi square dengan derajat kemaknaan $p<0,05$.

\section{HASIL}

Data dan Karakteristik Sampel

Tabel 1. Karakteristik Responden Penelitian Di Wilayah Kerja Puskesmas Padang Pasir

\begin{tabular}{|c|c|c|}
\hline Karakteristik & $\begin{array}{l}\text { Frekuensi } \\
\text { (n) }\end{array}$ & $(\%)$ \\
\hline \multicolumn{3}{|l|}{ Usia Ibu } \\
\hline 20-30 tahun & 62 & 57,9 \\
\hline $31-40$ tahun & 34 & 31,8 \\
\hline$>40$ tahun & 7 & 6,5 \\
\hline$<20$ tahun & 4 & 3,8 \\
\hline \multicolumn{3}{|c|}{ Tingkat Pendidikan Ibu } \\
\hline Tamat PT & 23 & 21,5 \\
\hline Tamat SMA & 58 & 54,2 \\
\hline Tamat SMP & 17 & 15,9 \\
\hline Tamat SD & 9 & 8,4 \\
\hline \multicolumn{3}{|l|}{ Pekerjaan Ibu } \\
\hline Buruh harian & 50 & 46,7 \\
\hline Pedagang & 25 & 23,4 \\
\hline Pegawai & 12 & 11,2 \\
\hline IRT/tidak bekerja & 20 & 18,7 \\
\hline \multicolumn{3}{|l|}{ Usia Bayi } \\
\hline $6-12$ bulan & 43 & 40,2 \\
\hline 13-18 bulan & 41 & 38,3 \\
\hline 19-24 bulan & 23 & 21,5 \\
\hline \multicolumn{3}{|l|}{ Jenis Kelamin Bayi } \\
\hline Laki-laki & 54 & 50,5 \\
\hline Perempuan & 53 & 49,5 \\
\hline
\end{tabular}

\section{Deskripsi Lokasi Penelitian}

Puskesmas Padang Pasir merupakan puskesmas yang terletak di Kecamatan Padang Barat, yang merupakan salah satu kecamatan yang ada di kota Padang, Sumatera Barat. Luas wilayah kecamatan Padang Barat adalah $7.000 \mathrm{~km}^{2}$ yang terdiri dari 10 kelurahan. 


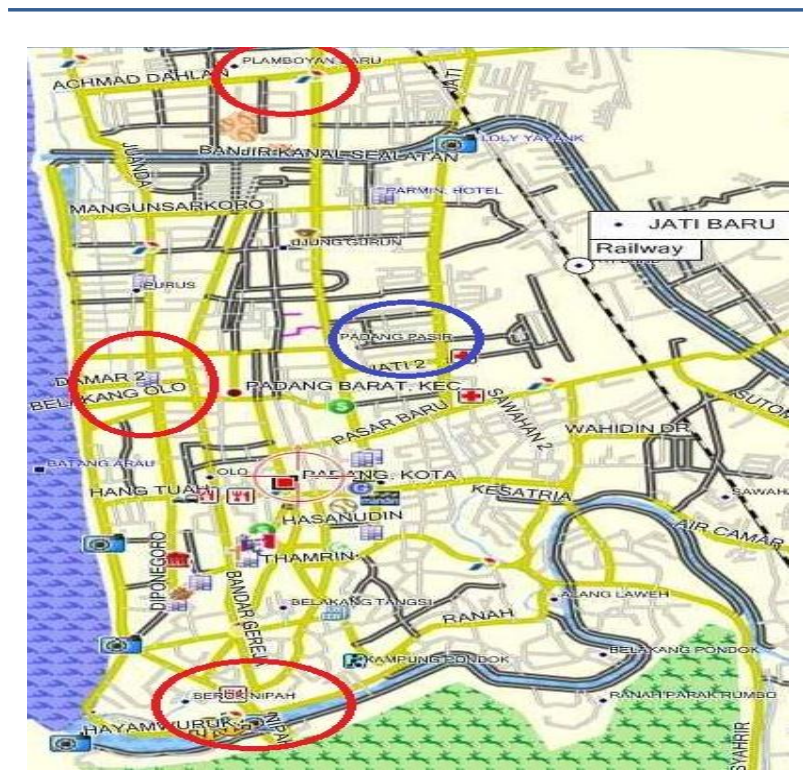

Gambar 1. Peta kecamatan Padang Barat

Tempat lokasi penelitian tidak berada jauh dari pinggir pantai. Adapun pengambilan subjek dilakukan secara simple random sampling. Hasil pengundian wilayah penelitian dilakukan di tiga kelurahan yang merupakan wilayah kerja Puskesmas Padang Pasir yaitu kelurahan Olo sebanyak 39 bayi, kelurahan Berok Nipah sebanyak 22 bayi, dan kelurahan Flamboyan sebanyak 46 bayi, sehingga didapatkan total subjek penelitian sebanyak 107 orang.

\section{Gambaran Status Gizi Bayi}

Tabel 2. Distribusi Frekuensi Status Gizi Bayi Menurut Indeks BB/TB

\begin{tabular}{lcc}
\hline \multicolumn{1}{c}{ Status gizi } & Frekuensi & $(\%)$ \\
\hline Gemuk & 14 & 13,1 \\
Normal & 88 & 82,2 \\
Kurus & 3 & 2,8 \\
Kurussekali & 2 & 1,9 \\
\hline Total & 107 & 100 \\
\hline
\end{tabular}

Untuk menghindari adanya sel kosong pada tabel uji silang maka kategori status gizi menurut indeks BB/TB diklasifikasikan lagi menjadi normal dan tidak normal.
Tabel 3. Distribusi Frekuensi Status Gizi Menurut Indeks BB/TB

\begin{tabular}{lcc}
\hline \multicolumn{1}{c}{ Status gizi } & Frekuensi & $(\%)$ \\
\hline Tidak Normal & 19 & 17,8 \\
Normal & 88 & 82,8 \\
\hline Total & 107 & 100 \\
\hline
\end{tabular}

\section{Gambaran Pemberian ASI Ekslusif}

Tabel 4. Distribusi Frekuensi Pemberian ASI Ekslusif

\begin{tabular}{ccc}
\hline $\begin{array}{c}\text { Pemberian ASI } \\
\text { ekslusif }\end{array}$ & Frekuensi & $\begin{array}{c}\text { Persentase } \\
(\%)\end{array}$ \\
\hline Ya & 20 & 18,7 \\
Tidak & 87 & 81,3 \\
\hline Total & 107 & 100 \\
\hline
\end{tabular}

\section{Gambaran Tingkat Pendidikan Ibu}

Tabel 5. Distribusi Frekuensi Tingkat Pendidikan lbu

\begin{tabular}{ccc}
\hline $\begin{array}{c}\text { Tingkat } \\
\text { pendidikan }\end{array}$ & Frekuensi & $(\%)$ \\
\hline Rendah & 25 & 23,4 \\
Tinggi & 82 & 76,6 \\
\hline Total & 107 & 100 \\
\hline
\end{tabular}

\section{Gambaran Status Ekonomi Keluarga}

Tabel 6.Distribusi Frekuensi Status Ekonomi Keluarga

\begin{tabular}{ccc}
\hline Status ekonomi & Frekuensi & $(\%)$ \\
\hline $\begin{array}{c}\text { SRp 326.705 } \\
\text { (miskin) }\end{array}$ & 21 & 19,6 \\
$>$ Rp 326.705 & 86 & 80,4 \\
(tidakmiskin) & & \\
\hline Total & 107 & 100
\end{tabular}

\section{Hubungan Pemberian ASI Ekslusif dengan Status} Gizi Bayi

Tabel 7. Hubungan Pemberian ASI Ekslusif Dengan Status Gizi Bayi

\begin{tabular}{ccc|cccc}
\hline \multirow{2}{*}{$\begin{array}{c}\text { Pemberian } \\
\text { ASI } \\
\text { Ekslusif }\end{array}$} & \multicolumn{2}{c}{$\begin{array}{c}\text { Status Gizi Bayi } \\
\text { Normal }\end{array}$} & Normal & & Total & $\begin{array}{c}\mathrm{p} \\
\text { value }\end{array}$ \\
\cline { 2 - 5 } & $\mathrm{n}$ & $\%$ & $\mathrm{~N}$ & $\%$ & & \\
\hline Tidak & 15 & 17,2 & 72 & 82,8 & 87 & \\
Ya & 4 & 20 & 16 & 80 & 20 & 0,752 \\
\hline Total & 19 & 17,8 & 88 & 82,8 & 107 & \\
\hline
\end{tabular}


Hubungan Tingkat Pendidikan Ibu dengan Status Gizi Bayi

Tabel 8. Hubungan Tingkat Pendidikan Ibu Dengan Status Gizi Bayi

\begin{tabular}{|c|c|c|c|c|c|c|}
\hline \multirow{3}{*}{$\begin{array}{c}\text { Tingkat } \\
\text { Pendidikan } \\
\text { Ibu }\end{array}$} & \multicolumn{4}{|c|}{ Status Gizi Bayi } & \multirow{3}{*}{ Total } & \multirow{3}{*}{$\begin{array}{c}p \\
\text { value }\end{array}$} \\
\hline & \multicolumn{2}{|c|}{$\begin{array}{c}\text { Tidak } \\
\text { Normal }\end{array}$} & \multicolumn{2}{|c|}{ Normal } & & \\
\hline & $\mathrm{n}$ & $\%$ & $\mathrm{~N}$ & $\%$ & & \\
\hline Rendah & 5 & 20 & 20 & 80 & 25 & \\
\hline Tinggi & 14 & 17,1 & 68 & 82,9 & 82 &, 100 \\
\hline Total & 19 & 17,8 & 88 & 82,2 & 107 & \\
\hline
\end{tabular}

\section{Hubungan Status Ekonomi Keluarga dengan Status Gizi Bayi}

Tabel 9. Hubungan Status Ekonomi Keluarga Dengan Status Gizi Bayi

\begin{tabular}{|c|c|c|c|c|c|c|}
\hline \multirow{3}{*}{$\begin{array}{c}\text { Status } \\
\text { Ekonomi } \\
\text { Keluarga }\end{array}$} & \multicolumn{4}{|c|}{ Status Gizi Bayi } & \multirow{3}{*}{ Total } & \multirow{3}{*}{$p$ value } \\
\hline & \multicolumn{2}{|c|}{ Tidak Normal } & \multicolumn{2}{|c|}{ Normal } & & \\
\hline & $\mathrm{n}$ & $\%$ & $\mathrm{~N}$ & $\%$ & & \\
\hline Miskin & 5 & 23,8 & 16 & 76,2 & 21 & \\
\hline Tidak Miskin & 14 & 16,3 & 72 & 83,7 & 86 & 0,524 \\
\hline Total & 19 & 17,8 & 88 & 82,8 & 107 & \\
\hline
\end{tabular}

\section{PEMBAHASAN}

\section{Karakteristik Responden}

Penelitian dilakukan di tiga kelurahan wilayah kerja Puskesmas Padang Pasir yang lokasinya berada tidak jauh dari Pantai Padang, yaitu Kelurahan Flamboyan, Kelurahan Olo dan Kelurahan Berok Nipah. Sebagian besar respondennya adalah ibu yang berusia $20-30$ tahun $(57,9 \%), 31-40$ tahun $(31,8 \%)$, usia $>40$ tahun $(6,5 \%)$ dan selebihnya berusia $<20$ tahun. Sebagian besar ibu yang menjadi responden adalah tamat SMA (54,2\%), disusul dengan tamat SMP $(15,9 \%)$, tamat perguruan tinggi $(21,5 \%)$, tamat SD $(8,4 \%)$ dan tidak ada yang tidak bersekolah.

Data pendukung mengenai tingkat pendidikan ibu didapatkan dari Kartu Keluarga (KK) dan ijazah yang diperlihatkan oleh ibu sebanyak 78 orang (72,9\%), namun terdapat 29 ibu $(27,1 \%)$ yang tidak dapat memperlihatkan data pendukung dikarenakan data tersebut tidak ada dan ibu tersebut tidak memiliki waktu untuk mencari data pendukung yang dibutuhkan peneliti. Oleh karena itu, data mengenai pendidikan ibu tersebut berdasarkan informasi yang diberikan oleh ibu tersebut.
Bayi yang menjadi responden dalam penelitian ini berusia $6-12$ bulan (40,2\%), 13-18 bulan $(38,3 \%)$, dan selebihnya berusia $19-24$ bulan $(21,5 \%)$. Jenis kelamin perempuan berjumlah 53 orang $(49,5 \%)$ dan laki-laki berjumlah 54 orang $(50,5 \%)$.

Data dari Puskesmas Padang Pasir didapatkan bahwa sebagian besar pekerjaan ibu yang berada di wilayah penelitian adalah buruh harian sebanyak 50 orang $(46,7 \%)$, ibu yang bekerja sebagai pedagang sebanyak 25 orang $(23.4 \%)$, ibu yang bekerja sebagai pegawai sebanyak 12 orang $(11,2 \%)$ dan ibu yang tidak bekerja atau sebagai ibu rumah tangga didapatkan sebanyak 20 orang $(18,7 \%)$.

\section{Hubungan Pemberian ASI Ekslusif dengan Status Gizi Bayi}

Berdasarkan Tabel 7 dapat dilihat bahwa sebagian besar status gizi bayi normal lebih banyak pada yang tidak diberi ASI ekslusif (82,8\%) daripada yang diberi ASI ekslusif (80\%).

Uji analisis statistik dengan Chi Square didapatkan hubungan pemberian ASI ekslusif dengan status gizi bayi diperoleh nilai $p>0,05(p=0,752)$ sehingga dapat disimpulkan bahwa tidak ada hubungan yang bermakna secara statistik antara pemberian ASI ekslusif dengan status gizi bayi.

Jumlah bayi yang diberi ASI ekslusif lebih sedikit dari bayi yang tidak diberi ASI ekslusif. Pemberian ASI ekslusif dipengaruhi banyak faktor, diantaranya sosial budaya, pengaruh promosi susu formula, dukungan petugas kesehatan, kesehatan ibu, kesehatan bayi, status pekerjaan ibu, tingkat pendidikan ibu dan pengetahuan serta sikap ibu. Pendidikan pada satu sisi mempunyai dampak positif yaitu ibu mengerti akan pentingnya pemeliharaan kesehatan termasuk pemberian ASI ekslusif. Namun pendidikan yang semakin tinggi juga akan berdampak adanya perubahan nilai sosial seperti anggapan bahwa menyusui dianggap tidak modern dan dapat mempengaruhi bentuk payudara ibu. Pemberian ASI pada bayi dianggap tidak modern dan menempatkan ibu pada kedudukan lebih rendah dibandingkan dengan ibu golongan atas. Pengetahuan dan sikap petugas kesehatan dalam memberikan penyuluhan tentang ASI sangat berpengaruh pada keberhasilan 
menyusui. Bayi yang sehat, tidak menderita kelainan atau penyakit tertentu lebih mudah untuk menyusu. Kondisi ibu yang tidak dianjurkan untuk menyusui bayi seacara permanen adalah ibu yang terinfeksi HIV. Hal ini untuk mencegah penularan ibu-anak melalui ASI. Tekanan ekonomi memaksa ibu bekerja untuk mencari penghasilan sehingga tidak mempunyai kesempatan memberikan ASI secara ekslusif. ${ }^{6,12}$

ASI ekslusif ditemukan tidak memiliki hubungan yang signifikan dengan status gizi pada penelitian yang dilakukan oleh Dinesh et al. Pada studi ini yang menjadi faktor yang berhubungan dengan status gizi adalah waktu memulai menyusui dan usia bayi saat diberi makanan tambahan. Hasil yang sama juga ditunjukkan oleh penelitian Mathew Mindo P. Simangunsong yang mendapatkan tidak adanya hubungan yang signifikan antara pemberian ASI ekslusif dengan status gizi bayi $(p=0,548) .{ }^{13}$

Novita Adelina dalam hasil penelitiannya juga menunjukkan tidak adanya hubungan yang signifikan antara pemberian ASI ekslusif dengan status gizi. ${ }^{14}$

Komposisi yang sesuai dengan kebutuhan bayi menjadikan ASI sebagai makanan tunggal untuk memenuhi kebutuhan pertumbuhan bayi sampai 6 bulan. ${ }^{15}$ Berdasarkan hasil penelitian didapatkan tidak adanya hubungan antara pemberian ASI ekslusif dengan status gizi bayi di wilayah kerja Puskesmas Padang Pasir. Hal ini dikarenakan pemberian ASI ekslusif bukan merupakan faktor mutlak penentu status gizi bayi. Adanya faktor lain yang mempengaruhi status gizi bayi tidak diteliti dalam penelitian ini. Hal ini yang kemungkinan membuat hasil penelitian menjadi tidak bermakna.

\section{Hubungan Tingkat Pendidikan Ibu dengan Status Gizi Bayi}

Pada Tabel 8 dapat diamati bahwa jumlah bayi yang berstatus gizi normal lebih banyak pada ibu yang memiliki tingkat pendidikan tinggi (82,9\%) daripada ibu yang berpendidikan rendah (80\%).

Berdasarkan hasil uji analisis statistik menggunakan rumus Chi Square antara tingkat pendidikan ibu dengan status gizi bayi, maka diperoleh nilai $p>0,05(p=0,768)$ sehingga dapat disimpulkan bahwa ternyata tidak terdapat hubungan yang bermakna secara statistik antara tingkat pendidikan ibu dengan status gizi.

Mathew Mindo P. Simangunsong dalam penelitiannya juga menunjukkan tidak terdapat hubungan yang bermakna antara tingkat pendidikan ibu dengan status gizi bayi. ${ }^{13}$

Seseorang yang hanya tamat sekolah dasar akan berbeda pengetahuan gizinya dibanding dengan yang pendidikannya lebih tinggi. Namun, belum berarti seseorang yang hanya tamat sekolah dasar kurang mampu menyusun makanan yang memenuhi persyaratan gizi. Hal ini dikarenakan jika orang tersebut rajin membaca informasi tentang gizi atau turut serta dalam penyuluhan gizi bukan mustahil pengetahuan gizinya akan lebih baik. Hanya saja perlu dipertimbangkan, seseorang yang memiliki tingkat pendidikan yang tinggi akan lebih mudah dalam menerima pesan dan informasi gizi. ${ }^{16}$

Pendidikan pada satu sisi mempunyai dampak positif yaitu ibu semakin mengerti akan pentingnya pemeliharaan kesehatan, tetapi di sisi lain pendidikan yang semakin tinggi juga akan berdampak adanya perubahan nilai sosial. ${ }^{12}$

Pada penelitian ini yang diteliti adalah tingkat pendidikan yang telah ibu selesaikan secara formal. Sedangkan pengetahuan ibu mengenai kesehatan tidak diteliti. Hal ini bisa menjadi salah satu faktor yang menyebabkan hasil penelitian tidak bermakna.

\section{Hubungan Status Ekonomi Keluarga dengan Status Gizi Bayi}

Dari Tabel 9 terlihat bahwa persentase bayi dengan status gizi normal lebih banyak pada keluarga dengan status ekonomi tidak miskin (83,7\%) dibanding keluarga dengan status ekonomi miskin (76,2\%).

Berdasarkan analisis statistik antara status ekonomi keluarga dengan status gizi bayi dengan menggunakan rumus Chi Square dapat disimpulkan bahwa tidak ada hubungan yang bermakna antara status ekonomi keluarga dengan status gizi bayi ( $p=$ 0,524).

Keluarga yang berada dalam garis kemiskinan tentunya kurang mampu menyediakan makanan yang bergizi yang nantinya akan berakibat gangguan gizi pada bayi. ${ }^{5}$ Pendapatan keluarga yang memadai akan menunjang perkembangan status gizi 
bayi karena orang tua mampu memenuhi semua

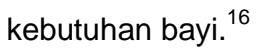

Pada penelitian ini tidak diteliti apakah pendapatan perkapita keluarga perbulan yang dialokasikan untuk pemenuhan kebutuhan gizi cukup untuk memenuhi kebutuhan gizi seluruh anggota keluarga sehari-hari. Faktor lain yang mempengaruhi status gizi bayi perlu diteliti lebih lanjut. Hal ini yang menyebabkan hasil penelitian tidak bermakna.

Banyak keterbatasan yang ditemukan selama melaksanakan penelitian. Kerjasama dan keterbukaan responden dalam penelitian menjadi salah satu faktor yang menghalangi peneliti untuk memperoleh data pendukung. Pemilihan variabel untuk mengetahui status gizi bayi kemungkinan belum dapat menggambarkan secara keseluruhan permasalahan yang ada karena terdapatnya faktor lain yang lebih berpengaruh terhadap status gizi bayi dibandingkan dengan pemberian asi ekslusif, tingkat pendidikan ibu, dan status ekonomi keluarga.

\section{KESIMPULAN}

Tidak terdapat hubungan yang bermakna antara pemberian ASI ekslusif dengan status gizi bayi. Tidak terdapat hubungan yang bermakna antara tingkat pendidikan ibu dengan status gizi bayi. Tidak terdapat hubungan yang bermakna antara status ekonomi keluarga dengan status gizi bayi.

\section{UCAPAN TERIMAKASIH}

Penulis mengucapkan terima kasih kepada dr. Yusri Dianne Jurnalis, Sp.A(K) dan dr. Selfi Renita Rusjdi, M.Biomed atas bimbingan, bantuan dan motivasi dalam penelitian ini.

\section{DAFTAR PUSTAKA}

1. Mansjoer A, Suprohaita, Wardhani WI, Setiowulan W. Kapita selekta. Edisi ke-3 Jilid 2. Jakarta: Media Aesculapius; 2000

2. Garis - garis Besar Haluan Negara. (diunduh 20 Maret2013). Tersedia dari: URL: HYPERLINK http://www.dephut.go.id/files/gbhn.pdf

3. Supariasa IDN, Bakri B, Fajar I. Penilaian status gizi. Jakarta: EGC; 2000.
4. Kusdarini E. Perlindungan anak sebagai perwujudan HAM dan generasi penerus bangsa. 2005 (diunduh 10 April 2013. Tersedia dari: URL: HYPERLINK http://staff.uny.ac.id/sites/defaults/ files/pengabdian/eny-kusdarini-sh-mhum/ppmperlindungan-anak-sebagai-perwujudan.pdf

5. Narendra BM, Sularyo TS, Soetjiningsih, Suyitno H, Ranuh IGNG. Tumbuh kembang anak dan remaja. Jakarta: Penerbit Sagung Seto; 2002.

6. Syarif DR, Lestari ED, Mexitalia M, Nasar SS. Buku ajar nutrisi pediatrik dan penyakit metabolik. Jilid I. Jakarta: Badan Penerbit Ikatan Dokter Anak Indonesia; 2011.

7. Peraturan Pemerintah Republik Indonesia Nomor 33 Tahun 2012. Tentang pemberian air susu ibu ekslusif. 2012 (diunduh 15 Februari 2013). Tersedia dari: URL: HYPERLINK http://www. depkes.go.id/dowloads/PP\%20ASI.pdf

8. Almatsier S. Prinsip dasar ilmu gizi. Jakarta: Gramedia Pustaka Utama; 2004.

9. Menkes RI. Tiga kelompok permasalahan gizi di Indonesia. 2012 (diunduh 1 Mei 2013). Tersedia dari: URL: HYPERLINK http://depkes.go.id

10. Profil Kesehatan Indonesia 2011 (diunduh 3 Januari 2013). Tersedia dari: URL: HYPERLINK http://www.depkes.go.id/downloads/PROFIL KE SEHATAN INDONESIA 2011.pdf

11. Profil Kesehatan Kota Padang 2011 (diunduh 6 Februari 2013). Tersedia dari: URL: HYPERLINK http://dinkeskotapadang1.wordpress.com

12. Sarbini D, Hidayati L. hubungan antara tingkat pendapatan keluarga dan pendidikan ibu dengan pemberian ASI ekslusif di kecamatan Jebres Kotamadya Surakarta. Surakarta: UMS; 2008.

13. Simangunsong MM. Hubungan antara status gizi bayi dengan jenis kelamin bayi, diare dan ISPA 14 hari terakhir, pemberian ASI Ekslusif, Usia lbu saat Melahirkan, Ibu yang Bekerja, Tingkat Pendidikan Ibu, dan Tingkat Penghasilan Keluarga. Jakarta: FKUI; 2009.

14. Novita A. Hubungan antara status gizi bayi dengan jenis kelamin bayi, diare dan ISPA 2 minggu terakhir, ASI ekslusif, usia lbu, ibu bekerja, tingkat pendidikan ibu dan tingkat penghasilan keluarga. Jakarta : FKUI; 2009. 
15. Arif N. ASI dan tumbuh kembang bayi. Jakarta: MedPress; 2009.
16. Soetjiningsih. Tumbuh Kembang anak. Jakarta: EGC; 1995. 